\title{
School Principals' Leadership Behaviours and its Relation with Teachers' Sense of Self-Efficacy
}

\author{
Vali Mehdinezhad \\ PhD. Faculty of Education and Psychology, University of Sistan and Baluchestan, Iran, \\ valmeh@ped.usb.ac.ir
}

\section{Masoumeh Mansouri}

MA. Faculty of Education and Psychology, University of Sistan and Baluchestan, Iran, mehdinezhad@gmail.com

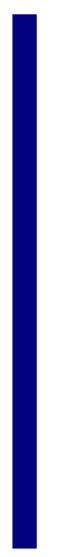

\begin{abstract}
The aim of this study was to investigate the relationship between school principals' leadership behaviours and teachers' sense of self-efficacy. The research method was descriptive and correlational. A sample size of 254 teachers was simply selected randomly by proportional sampling. For data collection, the Teachers' Sense of Efficacy Scale of Tschannen-Moran and Woolfolk Hoy (2001) and Leadership Multifactor Questionnaire of Bass and Avolio (1992) were used. Questionnaire validity was assessed by the type of content and their reliability was estimated by using Cronbach's alpha coefficient of 0.84 and 0.86 respectively. Pearson correlation coefficient test and stepwise regression were used to analyse the data. Research findings indicate that there is a significant relationship between the components of principals' leadership behaviours and teachers' sense of selfefficacy. The findings also showed that the two components of principals' leadership behaviours, that is, idealized influence and intellectual stimulation, can predict changes in teachers' sense of self-efficacy.
\end{abstract}

Key Words: principals' leadership behaviors, sense of self-efficacy, teacher, leadership, behavior

\section{INTRODUCTION}

One of the most powerful predictors of teacher impact on students is the idea that what he does is important. This idea is called as the teachers' efficacy. Teachers who believe that success in school is almost entirely due to children's innate intelligence, home environment or other factors are unlikely to make efforts to facilitate children's learning. A teacher who has a firm belief in its effectiveness is likely to make continuous efforts in the face of obstacles to persevere until every student is successful and hard-working (Bandura, 1997). Efficient teachers get to feel competent by continuous evaluation of the results of their training while they did not achieve their primary education. As such, they try new strategies and get fresh perspectives from colleagues, books, magazines, workshops and other resources to enrich and fortify their teaching skills. Groups of 
teachers can collectively review their methods and results to achieve professional development. In so doing, they can help each other to succeed and create a way of achieving collective efficiency. Collective efficiency can have a strong impact on the development of learners (Goddard, 2000).

One of the effectiveness measures for teachers to increase the teaching ability and improve the quality of learning is improving the quality of teaching. The role of the teacher in this process is simply speech making and the transfer of scientific facts, accumulating it in the minds of students. The teacher provides background and experience, through effective communication, to interested students in class and gives them lessons about the process of growth, knowledge of their behaviour and extensive information. In addition to the planned activity, the realization of educational goals with regular method to evaluate the effectiveness of their teaching and the academic achievement of learners is very paramount (Wragg, 2003).

Calik, Sezgin, Kavagaci, and Kilinc (2012) found out in a study about the relationships between school principals' instructional leadership behaviours and self-efficacy of teachers and collective teacher efficacy that instructional leadership had a significant direct and positive impact on collective teacher efficacy. Additionally, it seemed that teachers' self-efficacy moderated the relationship between instructional leadership and collective teacher efficacy. In another study conducted by Walker and Slear (2011) about the impact of principal leadership behaviours on the efficacy of teachers, it was shown that there was a positive link between principal behaviour and teacher efficacy.

The findings of Nir and Kranot (2006) suggest that the relation between the principal's leadership style and personal teacher efficacy is mediated by the positive experiences that teachers undergo on the job, mainly, on their satisfaction. According to Staggs (2002), teachers' perceptions of principals' leadership behaviour have an impact on the effectiveness of teachers in elementary schools, but do not affect the effectiveness of individual teachers. The guidance and perceptions of teachers about principals' leadership behaviours on the overall efficiency of teachers show that it has a positive impact on individual teachers. Also, this relationship in high school has a positive effect on the self-efficacy of teachers, but does not affect the effectiveness of teachers. Therefore, a review of studies on the relationship between leadership behaviours, and teachers' self-efficacy shows that there is a significant positive relationship between these two variables (Anderman, Noar, Zimmerman \& Donohew, 2004; Gay, Mills \& Airasian, 2006; Ghasemi, 2010; Kim \& Park, 2008; Griffin, 2009; Hipp, 1995; Nicolina, 2003; Pepper, 2010; Rieg \& Marcoline, 2008; Ross, Hogoboam-Gray \& Gray, 2004; Ross \& Gray, 2006; Ryan, 2007; Weisel \& Dror, 2006).

The main objective of this study was to determine the relationship between principals' leadership behaviours and teachers' sense of self-efficacy from the point of view of teachers in this context. The following research questions were processed.

-Is there a significant relationship between principals' leadership behaviours and its components with teachers' sense of self-efficacy?

-Are principals' leadership behaviours able to predict teachers' sense of self-efficacy? 


\section{METHOD}

The research method is descriptive and correlational. The target population of research included all teachers at Sabzevar City in Iran. Out of the 7482 teachers in the city, 1110 teachers were in the primary schools, 3320 teachers were in the middle schools, and 3052 teachers were in the secondary schools. The sample size of this study was based on a sample size table of Krejcie and Morgan (1970), of which a total number of 254 people comprising 98 male teachers and 156 female teachers were acquired. According to the sample size, the sampling method was simply random.

For data collection, two questionnaires were used. The first questionnaire was Teachers' Sense of Efficacy Scale of Tschannen-Moran and Woolfolk Hoy (2001). This questionnaire has two forms: long form ( 24 items) and short form (12 items). In this study, the long form of Tschannen-Moran and Woolfolk Hoy's TES, which was designed to portray the richness of teachers' work by focusing specifically on three constructs of teacher efficacy that impacts effectiveness in the classroom, was utilized: (1) efficacy in student engagement (ESE), (2) efficacy in instructional strategies (EIS), and (3) efficacy in classroom management (ECM). This scale was used to respond to statements from a five-item Likert range from very low $=1$ to very high $=5$.

The second questionnaire was the Persian version of Leadership Multifactor Questionnaire (LMQ-6s) of Bass and Avolio (1992). Out of seven factors, four factors were used in this research study. The factors used in this study were Idealized Influence (II), Intellectual Stimulation (IS), Inspirational Motivation (IM), and Individualized Consideration (IC). Therefore, 12 rerated items were selected in a whole five-item Likert range from not at all $=0$ to frequently, if not always $=4$. Score range was: HIGH $=9-12$, MODERATE $=5-8$, LOW $=0-4$. To estimate the reliability of the questionnaire, the Cronbach's alpha of 0.84 and 0.86 was used respectively.

For data analysis, Pearson correlation coefficient and stepwise regression were performed using SPSS software version 20.

\section{FINDINGS}

Is there a significant relationship between principals' leadership behaviors and its components with teachers' sense of self-efficacy?

Table 1: The correlation coefficient value between teachers' sense of self-efficacy with principals' leadership behaviours and their components $(\mathrm{N}=254)$

\begin{tabular}{|c|c|c|c|c|c|c|}
\hline & & $I I$ & $I S$ & $I M$ & $I C$ & LMQ (Total) \\
\hline \multirow[t]{2}{*}{ ESE } & $\mathrm{r}$ & $.559^{* * *}$ & $.540^{* * *}$ & $.467^{* * *}$ & $.436^{* * *}$ & $.581^{* * *}$ \\
\hline & Sig. & .001 & .001 & .001 & .001 & .001 \\
\hline \multirow[t]{2}{*}{ EIS } & $\mathrm{r}$ & $.446^{* * *}$ & $.430^{* * *}$ & $.417^{* * *}$ & $.330^{* * *}$ & $.471^{* * *}$ \\
\hline & Sig. & .001 & .001 & .001 & .001 & .001 \\
\hline \multirow[t]{2}{*}{ ECM } & $r$ & $.434^{\text {*** }}$ & $.386^{* * *}$ & $.407^{* * 6}$ & $.272^{* * *}$ & $.439^{* * *}$ \\
\hline & Sig. & .001 & .001 & .001 & .001 & .001 \\
\hline \multirow[t]{2}{*}{ TES(Total) } & $\mathrm{r}$ & $.548^{* * *}$ & $.517^{* * * 6}$ & $.493^{* * *}$ & $.395^{*, 4}$ & $.569^{* * *}$ \\
\hline & Sig. & .001 & .001 & .001 & .001 & .001 \\
\hline
\end{tabular}


The results of Table 1 show that there is a relatively high positive and significant relationship between the entire principals' leadership behaviours and teachers' sense of self-efficacy. In connection with the sub-components of the two variables, there is also a significant and positive relationship, though it is moderate. In this regard, the strongest connection between the two sub-components is the engagement of the students in activities of teaching and learning by teachers, while the weakest link between classroom management by teachers and support by individual managers is administrators' idealized influence.

Second question: Are principals' leadership behaviors able to predict teachers' sense of self-efficacy?

Table 2: Results of stepwise regression analysis to predict teachers' sense of selfefficacy by principals' leadership behaviours ( $\mathrm{N}=254)$

\begin{tabular}{ccccccccc}
\hline Step & $\begin{array}{c}\text { Independent } \\
\text { variable }\end{array}$ & $R$ & $R^{2}$ & Adj. $R^{2}$ & $\begin{array}{c}R^{2} \\
\text { Change }\end{array}$ & $B$ & $t$ & Sig. \\
\hline 1 & II & $.548 \mathrm{a}$ & .301 & .298 & .301 & 57.724 & 16.472 & .001 \\
& & & & & & .930 & 10.413 & .001 \\
\hline 2 & II+IS & $.566 \mathrm{~b}$ & .321 & .315 & .020 & 54.666 & 15.017 & .001 \\
& & & & & .630 & 4.457 & .001 \\
& & & & & & .749 & 2.711 & .007 \\
\hline
\end{tabular}

Table 2 shows the results of stepwise regression analysis to predict teachers' sense of self-efficacy by principals' leadership behaviours. The results of the regression analysis showed that idealized influence and intellectual stimulation with regression coefficient of 0.566 are able to predict $32.1 \%$ of teachers' sense of self-efficacy. In addition, the results show that these components with beta coefficient of 0.749 are significant at 0.007 . Thus, it can be mentioned that principals' leadership behaviours significantly predicted teachers' sense of self-efficacy.

\section{DISCUSSION}

The results showed that, in overall there is a significant positive relationship between the components of teachers' sense of self-efficacy and principals' leadership behaviours. The highest correlation coefficient was between the components of idealized influence and the students' engagement. The findings are consistent with those of Hipp (1995) who found out that principals' leadership behaviours directly and indirectly have an impact on the teachers' performance. Arnold (2001) showed that transformational leadership with trust, commitment and team performance are significantly related to and consistent with these results. The research by Nicolina (2003) also showed a significant relationship between transformational leadership style and effectiveness outcomes, which are consistent with these results. The findings of this study are also consistent with those of Ghasemi (2010) who found out that there exists a consistent significant relationship between transformational leadership style and self-efficacy. The research findings of Noorshahi (2009), which also showed that managers have the highest score in the component of idealized influence, are consistent with the results of this study. These findings are consistent with the findings of other investigators (Anderman et al., 
2004; Gay et al., 2006; Ghasemi, 2010; Kim \& Park, 2008; Griffin, 2009; Hipp, 1995; Nicolina, 2003; Pepper, 2010; Rieg \& Marcoline, 2008; Ross et al., 2004; Ross \& Gray, 2006; Ryan, 2007; Weisel \& Dror, 2006).

Stepwise regression analysis showed that in the first step idealized influence on the teachers' sense of self-efficacy was the most anticipated variable. This variable could alone predict $29 \%$ of teacher efficacy beliefs. In the second step, the variable of intellectual stimulation enters the predicted model and these two variables together caused $31 \%$ of changes of teachers' efficacy beliefs predicted. The movement variable of thought alone predicted $0.2 \%$ changes.

Today's organizations need leaders who, thanks to an exceptional personality and charisma, power, influence and broad vision, commitment and passion, the heat necessary for the use of the talents and subordinates, make efforts to achieve organizational goals. In this regard, the importance and necessity of management in education is much vital than in other organizations, because in an educational system, most schools of education managers, due to the size and extent of its dimension, are faced with serious responsibilities of advancing organizational goals (Jafari \& Yosefnezhad, 2002). One of the tasks of educational management is the effective role of leadership. As leaders and managers, through their behaviour, influence their followers, subordinates understanding from management and leadership under leadership behaviours are affected. Self-efficacy is an important factor in the workplace of organizations in that it can influence many aspects of human behaviour (Bandura, 1997). If a person believes that he cannot achieve the expected results or cannot prevent an unacceptable behaviour, he/she will be less motivated to do the job. Although there are other factors that act as a provocative measure of human behaviour, all of them are subject to individual belief. The result could lead to increased motivation and organizational performance thereby enhancing the self-efficacy of staff.

\section{CONCLUSION}

The main concerns of managers and leaders in the education system are how the behaviours displayed by teachers and the type of school in which they work can jointly increase their efficiency, with more effective formation. Therefore, if managers can display a symbolic mentality, training them to play the role of a leader will definitely have an effect on their followers. The leaders' way of life influences the beliefs, values and goals of the followers because they see them as heroes, as such it has a tremendous impact on the followers. The leaders verify the ideas and moral values of teachers to inspire them to think about the issues by using new methods, thus giving them extra motivation. The ability to evaluate the style and organizational implications of the teachers and looking forward to them creating a single vision and perspective in the future are the characteristics of this type of leadership (Bass \& Avolio, 1990). If educational leaders with idealized influence are able to play the role of a model by showing a level of ethical standards and providing a shared vision, they can gain the trust and respect of their followers, as such they will become humble, loyal and competent. Therefore, educational leaders with such features should implement programs that would show teachers how to behave accordingly with the objectives, 
programs and values of the educational system, in consistency with their beliefs. Also, they should provide an appropriate model for teachers in line with their goals and show them different ways of achieving those goals.

If educational leaders can forgo their individual desires and pursue the goals of groups and educational organizations, they can stimulate the respect of others and discourage other members from putting their personal interests above other interests. By so doing, teachers would intentionally put the training mission into use, thereby increasing students' achievement. Educational leaders should consider the educational system as a system with common goals; as such their behaviour should be consistent with other factors of the educational system. Considering the points of view of all other interested parties, a common vision should be outlined for the educational system for all to follow. As a result, teachers can play the role of a model.

To avoid the risk of mental stimulation, educational leaders should re-examine their basic assumptions and look for new ways of tackling issues. Teachers should be encouraged to look at issues from different perspectives and apply problem solving methods. Due to the extensive changes occurring in the social, economic, political, cultural and technical aspects of the community, organizations and educational system as an open system are faced with challenges caused by this change; thus educational leaders should bring up innovative initiatives that will give the teachers the spirit of risktaking to enable them overcome their fears and adapt with these changes and developments.

If educational leaders can pay attention to the behaviour and characteristics of its members such as the formation of the future image, highlighting the future, creating high-level and achievable goals, and showing enthusiasm in pursuing the team's goals particularly in the teachers, the teachers will be able to see the educational goals as the major objective and have big ambitions for optimization and high performance. Moreover, they will be more prepared to overcome obstacles. In addition, if educational leaders can show interest in the demands of others, take into cognizance the needs of individuals, communicate properly with individuals and allocate time to give tips to teachers and train them, they will be able to identify the strengths and weaknesses of their teachers. By so doing, they have contributed to the development of the teachers' abilities, thus leading them to their success. From the results of this study, it is observed that there is a significant and direct relationship between the elements of principals' leadership behaviours and teachers' sense of self-efficacy. However, the highest correlation between the components of idealized influence is seen in the engagement of students in educational activities.

It is observed that idealized influence on educational leaders represent their emphasis on trust, respect, dedication, role modelling, intuition, offering moral and noble values, paying attention to the moral consequences of their decisions and the creation of the landscape. Thus, implementing programs that will boost the efficiency and effectiveness of teachers would directly and indirectly affect student achievement, which is the goal of education. From the results of this study, the following suggestions are presented: 
1. Given that teachers' beliefs can affect all aspects of professional teaching, workshops should be developed in teacher training centres to strengthen the sense of self-efficacy of teachers.

2. Academicians suggested that human resource management and transformational leadership should be considered in the course of organizational behaviour. To be able to succeed in the field of management science, students, especially school administrators, should adopt this style of leadership.

3. According to the different dimensions of this type of leadership and its impact on outcomes such as satisfaction, commitment, efficiency, and citizen behaviour, this kind of leadership discussed in this study basically seeks to promote higher-level needs of followers. Therefore, given the current economic conditions, it is suggested that the basic needs and low level of job security should be given serious consideration.

\section{REFERENCES}

Anderman, E. M., Noar, S., Zimmerman, R., \& Donohew, L. (2004). The need for sensation as a prerequisite for motivation to engage in academic tasks. In M. L. Maehr \& P. R. Pintrich (Eds.). Advances in motivation and achievement, Volume 13: Motivating students, improving schools: The legacy of Carol Midgley (pp. 1-26). Greenwich, CT: JAI Press.

Bandura, A. (1977). Self-efficacy: Toward a unifying theory of behavioral change. Psychological Bulletin, 84(2), 191-215.

Bass, B.M. \& Avolio, B.J. (1992). Developing transformational leadership: 1992 and beyond. Journal of European Industrial Training, 14 (5), 21-27.

Bass, B.M., \& Avolio B.J. (1990). The implications of transactional and transformational leadership for individual, team, and organizational development. Research in Organizational Change and Development, 4(3), 231-272.

Calik, T., Sezgin, F., Kavagaci, H., \& Kilinc, A. (2012). Relationships between instructional leadership of school principals and self-efficacy of teachers and collective teacher efficacy. Educational Sciences: Theory \& Practice, 12(4), 2498-2504.

Gay, L. R., Mills, G. E., \& Airasian, P. (2006). Educational research: Competencies for analysis and application (8th Ed.). Ohio: Pearson Prentice Hall.

Ghasemi, Sh. (2010). The relationship between leadership style (transformational, exchange oriented, participatory) self-employee directors of the National Bank Alborz Province. The first international conference and innovation management.

Goddard, R. (2000). Collective teacher efficacy: Its meaning, measure, and impact on student achievement. American Educational Research Journal, 37(2), 47-507

Griffin, K. L. (2009). The relationship between self-efficacy of teachers and their perception of the school principal's leadership style (Doctoral dissertation). 
Hipp, K. (1995). Exploring the relationship between principals' leadership behaviors and teachers' sense of efficacy in Wisconsin middle schools. Paper presented at the annual meeting of the American Educational, Research Association, New York.

Jafari, S.A \& Yosefnezhad, F. (2002). Compare the performance of high school principals in the Isfahan city, and its relationship to relationship-oriented and taskoriented leadership style, Knowledge and research in psychology, 13-14, 25-38

Kim, M. \& Park, S. (2008). Structural relationship between principal leadership and teacher efficacy in middle school. The Journal of Korean Teacher Education, 25(3), 281-302.

Krejcie, R. V.; Morgan, D. W. (1970). Determining sample size for research activities. Educational and Psychological Measurement, 3(2), 607-610

Nicolina, A. (2003). Faculty and chair perspectives on leadership and its impacts on Departmental Outcomes. Thesis master of Arts McGill University.

Nir, A. E., \& Kranot, N. (2006). School principal's leadership style and teachers' self efficacy. Planning and Changing, 37(3-4), 205-218.

Pepper, K. (2010). Effective principals skilfully balance leadership styles to facilitate student success: A focus for the reauthorization of ESAE. Planning \& Changing, $41(1 / 2), 42-56$.

Rieg, S. A., \& Marcoline, J. F. (2008). Relationship building: The first " $R$ " for principals. Paper presented at the Eastern Education Research Association, Hilton Head, SC.

Ross, J., \& Gray, P. (2006). School leadership and student achievement: The mediating effects of teacher beliefs. Canadian Journal of Education, 29(3), 798-822. Retrieved from http://www.jstor.org/pss/20054196

Ross, J. A., Hogoboam-Gray, A., \& Gray, P. (2004). The contribution of prior student achievement and collaborative school processes to collective teacher efficacy in elementary schools. Leadership and Policy in Schools, 3(3), 163-188.

Rouge, E.C. (2003). Management class at school. Translation: Ali Reza Kiamanesh and Kamran Ganji, Tehran: growth.

Ryan, H. D. (2007). An examination of the relationship between teacher efficacy and teachers' perceptions of their principals' leadership behaviors. (Unpublished Doctoral Dissertation), University of North Texas, Dallas, TX.

Staggs, J. D. (2002). The relationships among teacher perceptions of principal leadership, teacher efficacy in a school improvement program. Unpublished Manuscript. Ohio State Ohio State University.

Tschannen-Moran, M.; Woolfolk Hoy, A. (2011). Teacher efficacy: capturing and elusive construct. Teaching and Teacher Education, 17(7), 783-805 
Walker, J., \& Slear, S. (2011). The impact of principal leadership behaviors on the efficacy of new and experienced middle school teachers. NASSP Bulletin, 95(1), 46-64.

Weisel, A., \& Dror, O. (2006). School climate, sense of efficacy, and Israeli teachers' attitudes toward inclusion of students with special needs. Education, Citizenship, and Social Justice, 1(2), 157-174.

\section{Turkish Abstract}

\section{Okul Müdürlerinin Liderlik Davranıșları ve Öğretmenlerin Öz-yeterlikleriyle İlișkisi}

Bu çalışmanın amacı okul müdürlerinin liderlik davranışlarıyla öğretmenlerin öz-yeterlikleri arasındaki ilişkiyi incelemektir. Araştırma yöntemi betimsel ve korelasyoneldir. 254 öğretmen oranlı örnekleme ile rassal olarak seçilmiştir. Veri toplama aracı olarak Tschannen-Moran ve Woolfolk Hoy (2001)'un Öğretmen Yeterlik Ölçeği ve Bass and Avolio (1992)'nun Çok faktörlü Liderlik Ölçeği kullanılmıştır. Ölçek geçerliği içerik türüne göre değerlendirilmiştir ve güvenirliği Cronbach Alfa katsayısıyla (sırasıyla .84 ve .86) hesaplanmıştır. Pearson korelasyon katsayı testi ve stepwise regresyon verileri analiz etmek için kullanılmıştır. Çalışmanın bulguları müdürlerin liderlik davranışları bileşenlerinin ögretmenlerin öz-yeterlik algılarıyla anlamlı derecede ilgili olduğunu göstermiştir. Bulgular ayrıca idealize edilmiş etki ve entelektüel simülasyon isimli iki liderlik bileşeninin öğretmenlerin öz-yeterlik algılarını yordadığını ortaya çıkarmıştır.

Anahtar Kelimeler: okul müdürlerinin liderlik davranışları, öz-yeterlik algısı, öğretmeni liderlik, davranış

\section{French Abstract}

Les comportements de Leadership de Principaux Scolaires et sa Relation avec le Sens de Professeurs d'Auto-efficacité

Le but de cette étude était d'examiner la relation entre les comportements de leadership des principaux scolaires et le sens des professeurs d'auto-efficacité. La méthode de recherche était descriptive et correlational. Une taille de l'échantillon de 254 professeurs a été simplement choisie aléatoirement par l'échantillonnage proportionnel. Pour la collecte de données, le Sens d'Échelle d'Efficacité des Professeurs de Tschannen-Moran et Woolfolk Hoy (2001) et le Questionnaire de Multifacteur de Leadership de Basse et Avolio (1992) ont été utilisés. La validité de questionnaire a été évaluée par le type de contenu et leur fiabilité a été évaluée en utilisant le coefficient alpha de Cronbach de 0.84 et 0.86 respectivement. Pearson le test de coefficient de corrélation et la régression point par point ont été utilisé pour analyser les données. Les découvertes de recherche indiquent qu'il y a une relation significative entre les composants des comportements de leadership des principaux et le sens des professeurs d'auto-efficacité. Les découvertes ont aussi montré que les deux composants des comportements de leadership des principaux, en somme, l'influence idéalisée et la stimulation intellectuelle, peuvent prévoir des changements du sens des professeurs d'auto-efficacité.

Mots Clés: les comportements de leadership de principaux, sens d'auto-efficacité, professeur, leadership, comportement

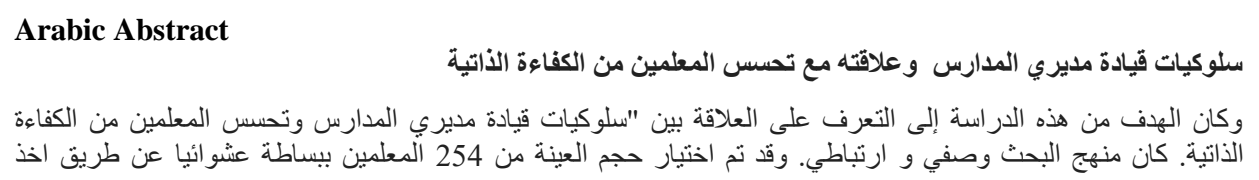




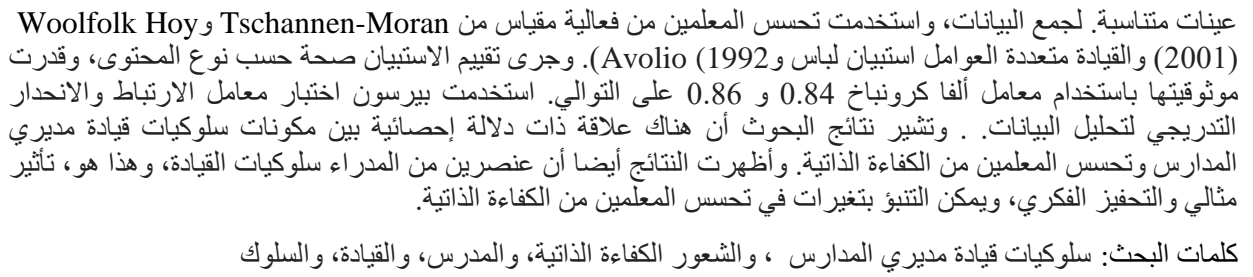

German Abstract

Führungsverhalten von Schulleitern und ihre Beziehung mit Sinn für Selbstwirksamkeit von Lehrern

Das Ziel dieser Studie war es, die Beziehung zwischen Führungsverhalten von Schulleitern und das Gefühl der Selbstwirksamkeit von Lehrern zu untersuchen. Die Forschungsmethode war beschreibend und correlational. Eine Stichprobengröße von 254 Lehrer war einfach zufällig durch proportionale Probenahme ausgewählt. Für die Datenerhebung der Sinn des Lehrers der Wirksamkeit Skala von Tschannen -Moran und Woolfolk Hoy (2001) und Führung Multi-FaktorFragebogen von Bass und Avolio (1992) verwendet. Fragebogen Gültigkeit wurde von der Art des Inhalts beurteilt und ihre Zuverlässigkeit geschätzt wurde von Cronbachs AlphaKoeffizienten von 0,84 und 0,86 jeweils verwendet wird. Pearson-Korrelationskoeffizienten-Test und schrittweise Regression wurden verwendet, um die Daten zu analysieren. zwischen den Komponenten der Haupt des Führungsverhalten und Lehrer Gefühl der Selbstwirksamkeit Forschungsergebnisse zeigen, dass es eine signifikante Beziehung ist. Die Ergebnisse zeigten auch, dass die beiden Komponenten des Prinzipals Führungsverhalten, das heißt, idealisierten Einfluss und intellektuelle Anregung, Veränderungen Gefühl der Selbstwirksamkeit des in der Lehrervorhersagen kann.

Schlüsselwörter: prinzipals führungsverhalten, das gefühl der selbstwirksamkeit, lehrer, führung, verhalten

\section{Malaysian Abstract}

\section{Tingkah Laku Kepimpinan Pengetua dan Perhubungan dengan Efikasi Kendiri Guru}

Tujuan kajian ini adalah untuk mengkaji hubungan antara tingkah laku kepimpinan pengetua dan efikasi kendiri guru. Kaedah penyelidikan adalah berbentuk deskriptif dan korelasi. Saiz sampel adalah 254 guru yang telah dipilih secara rawak oleh persampelan berkadar. Untuk pengumpulan data, efikasi kendiri guru diukur menggunakan Skala Tschannen-Moran dan Woolfolk Hoy (2001) dan Soal selidik kepimpinan pelbagai faktor Bass dan Avolio (1992) telah digunakan. Kesahan soal selidik dinilai menggunakan kesahan kandungan dan kebolehpercayaan menggunakan pekali alpha Cronbach yang mempunyai nilai masing-masing 0.84 dan 0.86 . Pearson ujian pekali korelasi dan regresi stepwise digunakan untuk menganalisis data. Dapatan kajian menunjukkan bahawa terdapat hubungan yang signifikan antara komponen tingkah laku kepimpinan pengetua dan efikasi kendiri guru. Dapatan kajian juga menunjukkan bahawa keduadua komponen tingkah laku kepimpinan pengetua, iaitu, pengaruh terunggul dan rangsangan intelek, boleh meramalkan perubahan dalam efikasi kendiri guru.

Kata Kunci: tingkah laku kepimpinan pengetua, efikasi kendiri, guru, kepimpinan, tingkah laku 